\title{
THE RELATIONSHIP AMONG VARIOUS MORPHOLOGICAL TYPES OF DIAMONDS WITHIN DIAMOND DEPOSITS IN RUSSIA: GENESIS, GROWTH, DISSOLUTION AND REAL DIAMOND GRADE
}

\author{
V.K. Garanin'1, A.V. Bovkun1, K.V. Garanin², G.Yu. Kriulina1, I.V. Serov² \\ ${ }^{1}$ Geological Faculty M..V.Lomonosov Moscow State University, Moscow, Russia, vgaranin@mail.ru, \\ bovkun2004@mail.ru,galinadiamond@gmail.com \\ ${ }^{2}$ PJSC ALROSA, Mirnyi, Sakha (Yakutia) Republic, Russia, GaraninKV@alrosa.ru, SerovIV@alrosa.ru
}

\section{Introduction}

Russia is the biggest diamond producer all over the World. There are more than 1500 kimberlites and related-rocks occurrences, 15 primary diamonds industrial deposits among them: Internatsionalnaya, Mir, Udachnaya, Aikhal, Nurbinskaya pipes, M.V. Lomonosov deposit and others. All of these deposits differ in diamond grade and quality.

The diamond content in industrial deposits is varying: between 0.25 (Zarnitsa pipe) and 8.71 (Internatsyonalnaya pipe) ct/t in Yakutia, between 0.5 (M.V. Lomonosova pipe) and 1.72 (Karpinskogo-1 pipe). There is a largest diamond deposit - Udachnaya pipe with total weight of diamonds -212591 ct. There are also numerous of placer diamond deposits in Russia, inlude unique placers in the Northern (Ebelyakh, Molodo, Morgogor, Talaktakh and others) and Central (Vodorazdelnye galechniki, Irelyakh, Gornoe, Solur-Vostochnaya, Ruchei Piropovyi, Nurbinskaya and others). The price per carat is also different for deposits: from 45 (Aikhal pipe) to >200 (Komsomolskaya pipe) \$/ct, with forecast (2016-2030) average 135\$/t (Micon, 2016). Fantasy colored high-value diamonds (reddish, green, yellow and others) are also presented in Russian diamond deposits. Every years several large crystalls ( $>50 \mathrm{ct} / \mathrm{stone})$ recovered from kimberlitic pipes and placers in Russia including the biggest diamond 888.06 ct from Yubileynaya pipe (in 2013) (Fig. $1)$.

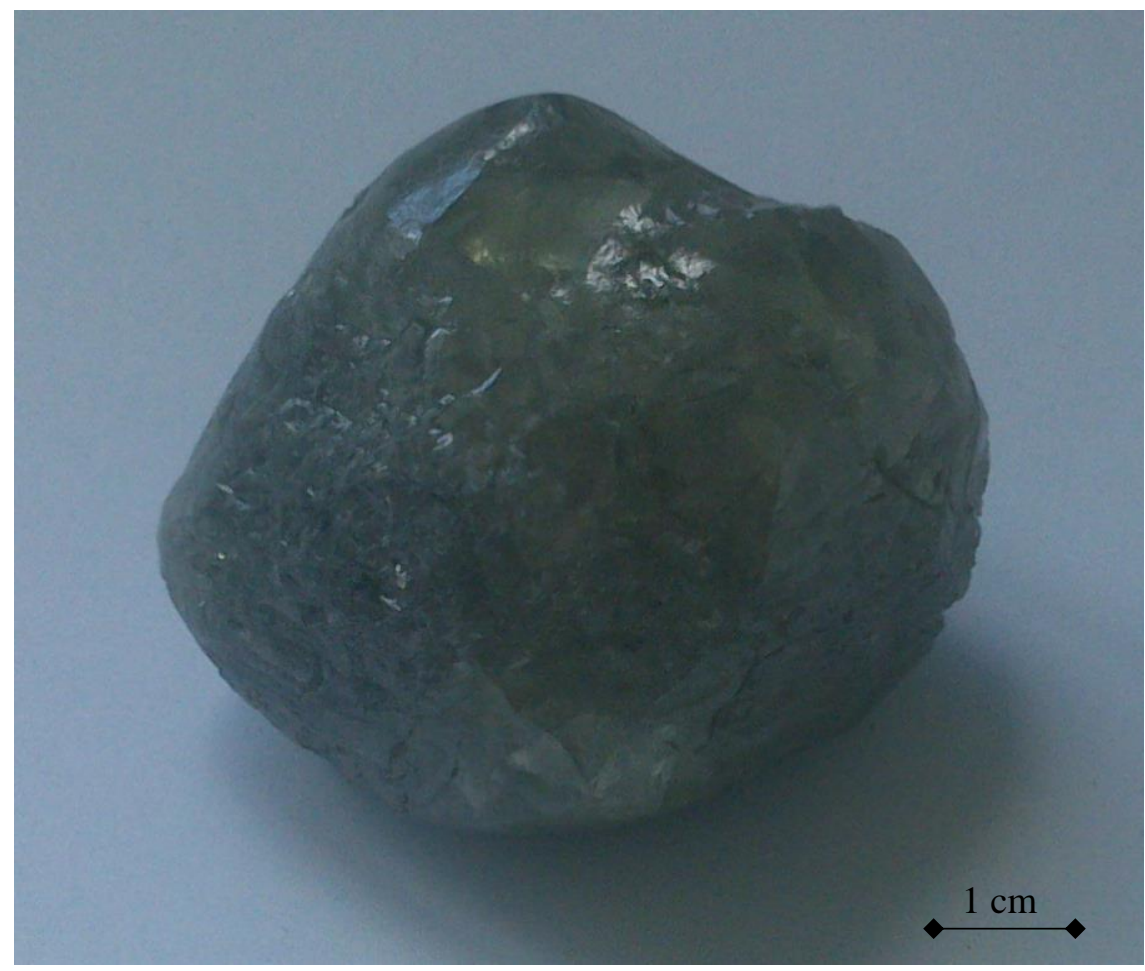

Figure 1: The largest Russian diamond (888.06 ct) recovered from Yubileynaya pipe in 2013. (K. Garanin photo) 
Generally diamonds in kimberlites located as xenocrysts with size from microns to several centimeters, and also rarely in mantle xenoliths (peridotites and eclogites) within kimberlites.

Additionally diamonds of each deposit are characterized by own gradation, morphology, color characteristics, physical features, etc. These characteristics correlate with mineralogical indicating features: content of main diamond indicator minerals (garnet, clinopyroxene, chromite and ilmenite), its proportion and presence among these minerals grains of diamond paragenesis association. Kimberlites of industrial deposits contain also significant assemble own kimberlitic indicator minerals: high-chromium and low-titanium spinellids, picroilmenites, and low content of perovskite and rutile.

\section{Scope of study}

Mineralogical data on diamonds, kimberlitic indicator minerals and own kimberlitic minerals for kimberlitic occurences and 15 diamond deposits in Russia was combined in united database. The database provides opportunity to solve numerous scientific, exploration and technological problems. This database is a technique for identification potential and real diamond grade in kimberlites. The architecture of analiticalsystem for diamond is presented is presented in Fig. 2.

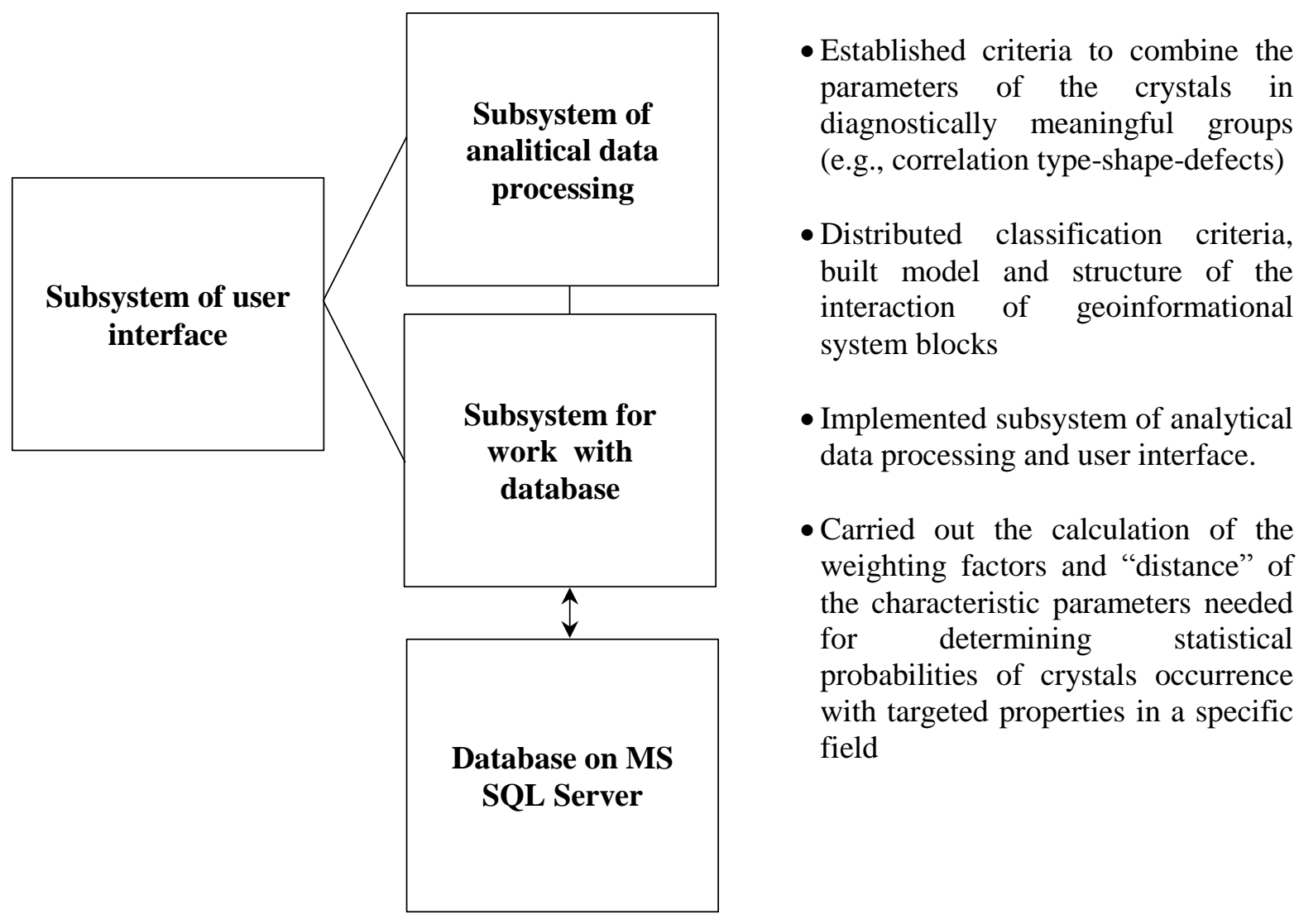

Figure 2: General scheme of analytical system architecture for diamond

\section{Study results}

Three petrochemical types of kimberlites were suggested and each of these types have been characterized by indicative parameters: $\mathrm{TiO}_{2}$ and other rock-forming oxides content, LREE, HREE, CHUR, rock-forming minerals characterisitcs, groundmass mineralogy, diamond indicator minerals, source of titanium, mantle source (Table 1). 


\begin{tabular}{|c|c|c|c|}
\hline Parameter & Low-titanium & Moderate-titanium & Highly-titanium \\
\hline $\mathrm{TiO}_{2}$, wt. \%, & $<1$ & $1-2.5$ & $>2.5$ \\
\hline $\begin{array}{l}\text { LREE (La, Ce, Sm, } \\
\text { Nd) }\end{array}$ & $\begin{array}{l}\text { Moderate (fluid } \\
\text { metasomatosis) }\end{array}$ & Low & High, La/Yb ratio $\sim 70-130$ \\
\hline $\begin{array}{l}\text { HREE (Nb, Zr, Ta, } \\
\text { Hf, Th,U) }\end{array}$ & Low & Moderate & High \\
\hline CHUR $\varepsilon_{\mathrm{Nd}}$ & $\sim-6$ up to +2 & $-0.4+1.0$ & $\begin{array}{l}+1.7,+1.2 \text { (Kepinskoe Field) } \\
-+3,+4 \text { (Olenekskaya Area) }\end{array}$ \\
\hline $\begin{array}{l}\text { Main rock-forming } \\
\text { minerals }\end{array}$ & $\begin{array}{l}\text { Olivine, calcite, } \\
\text { phlogopite }\end{array}$ & $\begin{array}{l}\text { Olivine, calcite, } \\
\text { phlogopite }\end{array}$ & Olivine, calcite, phlogopite \\
\hline Rock matrix & Cr-spinellid & $\begin{array}{l}\text { Cr-spinellids+ilmenite, } \\
\text { perovskite, rutile }\end{array}$ & $\begin{array}{l}\text { Altered: Ti-chromite, Ti- } \\
\text { magnetite, rutile, ilmenite }\end{array}$ \\
\hline $\begin{array}{l}\mathrm{HFM} / \text { diamond } \\
\text { assemble minerals }\end{array}$ & $\begin{array}{l}\downarrow \text { Cr-spinel, Cr-pyrope- } \\
\text { almandine, Cr-diopside, } \\
\text { Mg-olivine }\end{array}$ & $\begin{array}{l}\uparrow \underline{\text { Picroilmenite, }} \text {, pyrope- } \\
\text { almandine, } \mathrm{Cr}- \\
\text { diopside, } \mathrm{Mg} \text {-olivine }\end{array}$ & $\begin{array}{l}\text { Picroilmenite, Cr-spinel, Cr- } \\
\text { pyrope, Cr-diopside }\end{array}$ \\
\hline HFM weight, $\mathrm{kg} / \mathrm{t}$ & $0.1-9.7$ & $20-50$ & $<14$ \\
\hline $\mathrm{Ti}$ & $\begin{array}{l}\text { Ti-garnet (0.4-1.5 wt. \% } \\
\left.\mathrm{TiO}_{2}\right)\end{array}$ & $\mathrm{FeTiO}_{3}, \mathrm{CaTiO}_{3}, \mathrm{TiO}_{2}$ & $\mathrm{FeTiO}_{3}, \mathrm{CaTiO}_{3}, \mathrm{TiO}_{2}$ \\
\hline Mantle & $\begin{array}{l}\text { Enriched ancient mantle } \\
\text { type I (EMI) }\end{array}$ & $\begin{array}{l}\text { Close to BSE, depleted, } \\
\text { metasomatosised, Pb- } \\
\text { enriched }\end{array}$ & Depleted \\
\hline
\end{tabular}

Table 1: Petrochemical types of kimberlites in Russia

According to integrated data processing through database it was indicated - there are several populations (generations) of diamonds within every kimberlite body. Each deposit has own features of diamond crystallization in mantle, evolution of diamond matter in metasomatized mantle, complex processes of growth and dissolution of diamond in mantle and further environments within kimberlitic-generated and kimberlite-bearing melts. It was identified the conditions of diamond genesis, growth and dissolution are rather complex, sometimes with long variable crystallization processes in heterogeneal environments. All of these processes directly and indirectly have an impact on crystallization of mantle and kimberlitic minerals. For this reason, based on these minerals investigation, it is possible to detect signs of high or relatively low diamond content of diamonds in the deposit and its quality. It certainly gives every reason for effective production of diamonds with advanced planning at low cost mining.

\section{Conlusion}

The developed system is a set of database, original software, and technological schemes of processing newly received data on the diamond, diamond indicator minerals (DIM) and indicator minerals of kimberlites (IMK). That solves a lot of research and industrial problems associated with qualitative and quantitative evaluation of diamond deposit. In addition, collected data provide unique exploration tools for discovery new diamond deposits not only in Russia, but also in other regions of the World.

\section{References}

Micon Int Co Ltd (2016) Independent experts report on reserves and resources of ALROSA Group diamond deposits in Russia, 471 p. In Russian 